ISSN 0103-5150

Fisioter. Mov., Curitiba, v. 28, n. 1, p. 107-115, Jan./Mar. 2015

Licenciado sob uma Licença Creative Commons

DOI: http://dx.doi.org.10.1590/0103-5150.028.001.A011

(c) (9)

\title{
Effect of mode of delivery and parities on the occurrence of urinary incontinence during pregnancy
}

\author{
Efeito da via de parto e paridades sobre a ocorrência \\ de incontinência urinária no período gestacional
}

\author{
Mônica Cruvinel de Lima ${ }^{[a]}$, Gislaine Barreto Amaral Moccelin ${ }^{[b]}$, Mayara Bogarim da Silva ${ }^{[a]}$, \\ Gabriel Bogalho Nogueira ${ }^{[a] *}$ \\ [a] Centro Universitário Anhanguera, Campo Grande, MS, Brazil \\ [b] Faculdade de Medicina de São José do Rio Preto (Famerp), São José do Rio Preto, SP, Brazil
}

\begin{abstract}
Introduction: The urinary incontinence (UI) is a common pathology among women. In the gestation period, it is even more predominant, affecting between $20 \%$ and $67 \%$. Objective: To evaluate the relation between modes of delivery and parity on the occurrence of urinary incontinence during pregnancy. Methodology: 80 pregnant and postpartum women, treated at the Hospital da Mulher, in Campo Grande, MS, Brazil, were selected during September and October 2011, following the inclusion and exclusion criteria of the research. The evaluation protocol consisted of a questionnaire on the clinical history of the patients, gynecological complications, urogynecologic and obstetric information. Results: For independent samples, the comparison
\end{abstract}

\footnotetext{
* MCL: MSc, e-mail: monicacruvinel@hotmail.com GBAM: Grad., e-mail:guezinh@gmail.com MBS: Grad., e-mail: mayarabogarim@gmail.com GBN: MSc, e-mail: gabriel_bogalho@yahoo.com.br
} 
between the main values observed for the UI was given by the Mann-Whitney test and correlations between urinary incontinence and other variables were given by the Spearman's rank correlation coefficient. The studied group consisted of $40(50 \%)$ primiparous and $40(50 \%)$ multiparous women. The correlation between the following variables was not significant: parity and UI $(r=0.04, p=0.7)$; parity and SUI $(r=-0.81$, $\mathrm{p}=0.5)$; and parity and urge incontinence $(\mathrm{r}=0.14, \mathrm{p}=0.19)$. In addition, the correlation obtained between vaginal delivery and the presence of urinary incontinence in primiparous $(r=0.08, p=0.61)$ and in multiparous $(r=-0.05, p=0.76)$ was also not significant. The same occurs when cesarean delivery is correlated to urinary incontinence in primiparous $(r=-0.08, p=0.61)$ and multiparous women $(r=-0.10, p=0.5)$. Conclusion: Parity and mode of delivery were not significantly associated with the occurrence of urinary incontinence during pregnancy.

Keywords: Urinary incontinence. Pregnancy. Parity. Obstetrical delivery.

\section{Resumo}

Introdução: A incontinência urinária (IU) é uma patologia comum entre as mulheres. No período gestacional, é ainda mais prevalente, acometendo entre 20\% e 67\% das gestantes. Objetivo: Avaliar a relação entre via de parto e paridade na ocorrência de incontinência urinária no período gestacional. Metodologia: Foram selecionadas 80 (oitenta) gestantes e puérperas atendidas no Hospital da Mulher, em Campo Grande, MS, no período compreendido entre setembro e outubro de 2011, obedecendo aos critérios de inclusão e exclusão da pesquisa. o protocolo de avaliação constituiu-se de um questionário contendo dados referentes a história clínica da paciente, complicações ginecológicas, informações uroginecológicas e obstétricas. Resultados: A comparação entre as médias dos valores observados em relação à IU foram realizadas pelo teste Mann-Whitney para amostras independentes e correlações entre a incontinência urinária e as demais variáveis foram realizadas pelo teste de correlação linear de Spearman. O grupo de mulheres estudadas consistiu-se de 40 primíparas (50\%) e 40 multíparas (50\%). Não se mostraram significativas as relações entre paridade e IU $(r=0,04 ; p=0,7)$, paridade e IUE $(r=-0,81 ; p=0,5)$ e paridade e UI $(r=0,14 ; p=0,19)$. Também não se obteve significância de correlação entre parto vaginal e presença de incontinência urinária em primíparas $(r=0,08 ; p=0,61)$ e multíparas $(r=-0,05$; $p=0,76)$, assim como quando correlacionado o parto cesariano com a incontinência urinária em primíparas $(r=-0,08 ; p=0,61)$ e multíparas $(r=-0,10 ; p=0,5)$. Conclusão: A paridade e a via de parto não estiveram relacionadas de forma significativa com a ocorrência de incontinência urinária no período gestacional.

Palavras-chave: Incontinência urinária. Gestação. Paridade. Parto obstétrico.

\section{Introduction}

The urinary incontinence is defined by the International Continence Society (ICS) as any involuntary leakage. The prevalence of urinary incontinence varies a lot mainly according to the type of population and the different age range which were studied, occurring more in women than in men. It is estimated that one out of four women has some kind of urinary loss (1).

The urinary incontinence consists of three types: Stress Urinary Incontinence (SUI), which is the complaint for involuntary leakage during stress, physical exercise, when sneezing or coughing; Urge
Urinary Incontinence or Urge Incontinence (UI), which is the complaint for involuntary leakage preceded by a sudden and uncontrollable urge of urining, difficult to be delayed; and Mixed Urinary Incontinence (MUI), which is the involuntary leakage associated with urge and also with stress, exercises, sneeze or cough (2).

The prevalence of urinary incontinence varies from $37.5 \%$ during pregnancy to $51.7 \%$ in the puerperium. This fact happens most of the time for the first time during pregnancy and it is transitory in many cases. In this period, the pelvic floor muscles suffer a long resistance test and are extremely requested in the body changes. However, such prevalence can 
increase if there are repeated pregnancies, due to the obstetrical traumas (3).

In spite of the high prevalence, only one fourth of the women look for help to the problem owing to lack of information about possible treatments and also because they think it is a natural process (4).

Amongst the UI types, during pregnancy, the most frequent is the SUI (from 5 to 69\%). The urge incontinence has prevalence from 4 to $55 \%$ and the MUI, from 3 to $35 \%$. According to some authors, the SUI rarely occurs for the first time after delivery without having occurred earlier during pregnancy and may remain after delivery, disappear in the puerperium or remain and get more severe by subsequent pregnancies (6).

The urinary incontinence (UI) has pregnancy and delivery as main risk factors, mainly during the reproductive years of women, particularly the vaginal delivery, as a result of the injuries that may be caused in the musculature and innervation in the pelvic floor. This musculature and innervation represent an important factor in the continuity of the urinary incontinence (1).

During pregnancy, there are moments of significant anatomical and physiological changes in the mother's organism, especially for the urinary tract, which can result in alteration in function, manifested by SUI (7).

The hormonal and mechanical factors favor the increase of the urinary symptoms and the incidence of gestational urinary leakage, being the increase of the voiding frequency more common as well as the aggravation of urge voiding, of the urge incontinence and the urinary incontinence due to stress during pregnancy, which may persist in $50 \%$ of women after delivery (8).

In the pregnancy, the baby's weight plus the placenta provide an overload during several months on the mother's pelvic floor. In the process of pregnancy, there is an increase of intra-abdominal pressure, which is transmitted to the bladder. And because of the new positioning of the proximal portion of the urethra, there is some difficulty in the transmission of the intra-abdominal pressure to the urethra due to the uterine volume, provoking urinary incontinence (9).

The pregnancy physiological alterations, such as anatomical relations modifications between bladder and womb, pelvic floor reduction (PF) which anchors the bladder neck, and also high levels of progesterone and detrusor instability are associated as arguments which can explain the non-protection attributed to the Caesarian section (1).

The SIU is generally attributed to the disability of the perineum muscles to assure intra- urethral pressure levels higher than the ones of the intra-bladder pressure. It is understood that the weakness of the perineum muscles is associated to the ageing process and/or to pregnancy and vaginal delivery, to the number of pregnancies and deliveries or even to the reduction of muscle fibers of type I (10).

It seems that the number of deliveries is associated with a bigger prevalence of urinary incontinence, having this increase from the third delivery on (11). In a study with 160 primiparous women, it was observed, through MRI (magnetic resonance), that $20 \%$ of them showed lesion of the levator ani muscle, between nine and twelve months after vaginal delivery (12).

As far as obstetric history is concerned, risk is observed to be approximately ten times higher of SIU in patients with one or more pregnancies in comparison to nulliparous women. Similar data have been found in other studies where risk was five times higher (1).

Multiple births are considered a risk factor when the association of UI in women who had vaginal delivery is analyzed. In the study, cephalic perimeters bigger than 34 centimeters were statistically significant for the presence of UI in multiparous women (13).

The presence of irritating urinary symptoms has been documented in some studies with pregnant women, although they are supposed to reduce or even disappear in the post-partum period. This fact does not interfere in these women's quality of life after childbirth. There are no evidences amongst the types of delivery, but some studies show a bigger relation of the symptom with multiple births (14).

The impact of vaginal delivery in the muscles of the pelvic floor may alter the awareness and muscles control, but it was seen that through perineometry, these muscles were restored ten weeks after delivery. According to some authors, the Caesarian section possibly avoids the appearance of disturbances of the pelvic floor due to obstetric trauma and it can be a protection against the development of urinary incontinence of postpartum stress (15).

Nowadays there has been increasing interest in options for more conservative treatments. Therefore, depending on the type and severity of UI, the physiotherapic treatment has been recommended as a way of initial approach (16). 
The adverse circumstances of identification of the precise nature of some risk factors related to the appearance of leakage during pregnancy and the characteristics of its evolution make the elaboration of proposals for the preventive approach of this problem difficult. The knowledge about prevalence of this symptom may contribute for the elaboration of projects that aim to improve the attention quality provided during prenatal period by health-care professionals, as well as developing preventive strategies by physiotherapy. Thus, this study aimed to evaluate the correlation between the mode of delivery and parity over the urinary incontinence occurrence during pregnancy.

\section{Method}

This is a cross-sectional study. The data were collected from September to October, 2011 at the "Hospital da Mulher - Vó Honoria Martins Pereira", situated at Guarabu da Serra Street, Moreninha III, in the city of Campo Grande, MS, Brazil.

To conduct this study, pregnant and puerperal women who were in immediate labor and puerperium have been orally invited by the responsible researcher, following the inclusion and exclusion criteria of the research. The sample consisted of 80 (eighty) subjects of the female sex aged between 18 and 36 years old, who were admitted to the "Hospital da Mulher de Campo Grande", MS, Brazil. All pregnant and puerperal women who accepted taking part on the present study were included, after reading and signing a free informed consent: pregnant women aged between 18 and 36 years old, multiparous and primiparous women and pregnant women from the $38^{\text {th }}$ week on. Women who were cognitively disabled or had any other situation which prevented them from reading and understanding both the free informed consent and the researcher's questions, women who had undergone previous perineal surgeries, diabetes; medication which interfere in the lower urinary tract function, women who had asthma, were considered as exclusion criteria.

\section{Physioterapic evaluation protocol}

The volunteers have been through an evaluation protocol which consisted of: patient's identification, which remained totally confidential, medical history, main complaint, gynecological complications, questions about urogynecological (urinary symptoms) and obstetric information.

The volunteers answered this questionnaire in a very comfortable position. After data collection, the data analysis was worked out, thus, it was possible to check the correlation between parity, pregnancy and urinary incontinence in the assisted patients.

This study was approved by the Ethical Committee in Human Beings Research of Anhanguera Educacional Ltda. college, under 1941/2011 protocol according to the Resolution nr 196/1996 of the Health Federal Council.

\section{Statistical analysis}

The data concerning age, weight gain, numbers of pregnancies, deliveries or abortions were represented by the average and average standard deviation and the comparison between averages carried out by the non-paired test.

The comparison among the averages of the observed values in relation to UI, complications, UI period and discomfort in the primiparous and multipareous groups were performed by the MannWhitney test for independent samples, on a nonparametric basis.

The correlations between urinary incontinence and the other variables were carried out by the Spearman linear correlation Test. The values of $p$ under 0.05 were considered significant.

\section{Results}

The age amongst primiparous women ranged between 18 and 33 years old, with average of $22.9 \pm 3.9$ years (average \pm average standard deviation) while the age amongst multiparous women ranged between 18 and 36 years old with average of $25.2 \pm 4.9$ years. The difference between age average of both groups was significant.

The weight gain of primiparous women during pregnancy ranged between 3 and $28 \mathrm{~kg}$, with average of $13.2 \pm 5 \mathrm{~kg}$ (average \pm average standard deviation) and the weight gain of multiparous women ranged between 6 and $22 \mathrm{~kg}$ with average of $12.1 \pm$ $3.7 \mathrm{~kg}$. The difference between average weight of both groups was not significant. 
The correlation between weight and urinary incontinence in the primiparous women's group $(\mathrm{r}=-0.22 ; \mathrm{p}=0.16)$ was not significant as well as the comparison made with the multiparous women $(\mathrm{r}=8.7 ; \mathrm{p}>0.99)$.

In the multiparous women's group the average value of the number of pregnancies was $2.9 \pm 1.1$ pregnancies while the number of deliveries was $2.7 \pm$ 1.0 deliveries and the number of abortions was $0.1 \pm$ 0.3 abortions.

According to the number of pregnancies in the multiparous group, 47.55 of women $(n=19)$ had two pregnancies; $32.5 \%(n=13)$ had three pregnancies; $10 \%$ of women $(\mathrm{n}=4)$ had four pregnancies; $7.5 \%$ $(n=3)$, five pregnancies and women who had six pregnancies $(\mathrm{n}=1)$ were $2.5 \%$.

According to the number of deliveries carried out in women from the multiparous group, it was observed that $2.5 \%$ of them had one delivery ( $\mathrm{n}=$ 1); $50 \%$ of the women $(n=20)$ had two deliveries; $30 \%(n=12)$ had three deliveries; $10 \%(n=4)$ had four deliveries; $5 \%(n=2)$ had five deliveries; while $2.5 \%$ had six deliveries $(n=1)$.

Wtih regard to the number of abortions, $10 \%$ $(n=4)$ of the multiparous women suffered a miscarriage, while in the group of primiparous women $7.5 \%$ $(n=3)$ had two pregnancies and consequently, the same number of abortions. The difference regarding the average number of abortions in both groups was not significant.

The 40 multiparous women involved in this study carried out 110 deliveries in total, of those $68 \%$ $(n=75)$ vaginal deliveries and $32 \%(n=35)$ caesarean deliveries, however some women carried out both types of delivery. Among the 40 primiparous women, $60 \%(n=24)$ carried out vaginal deliveries and $40 \%$ $(\mathrm{n}=16)$, caesarean deliveries. The graphic representation of this distribution is shown in Figure 1.

With regard to the 80 women who participated in this study, there was no significant correlation between parity and $U I(r=0.05 ; p=0.6)$, between parity and IUE ( $\mathrm{r}=-0.81 ; \mathrm{p}=0.5$ ) as well as between parity and urge incontinence $(r=0.2 ; p=0.07)$.

There was no significant correlation between vaginal delivery and the presence of urinary incontinence either in the primiparous group $(\mathrm{r}=0.08 ; \mathrm{p}=0.61)$ or in the multiparous group $(\mathrm{r}=-0.12 ; \mathrm{p}=0.5)$, as well as the correlation between caesarean delivery and urinary incontinence in the primiparous $(r=-0.04$; $\mathrm{p}=0.61)$ and multiparous group $(\mathrm{r}=-0.04 ; \mathrm{p}=0.76)$.

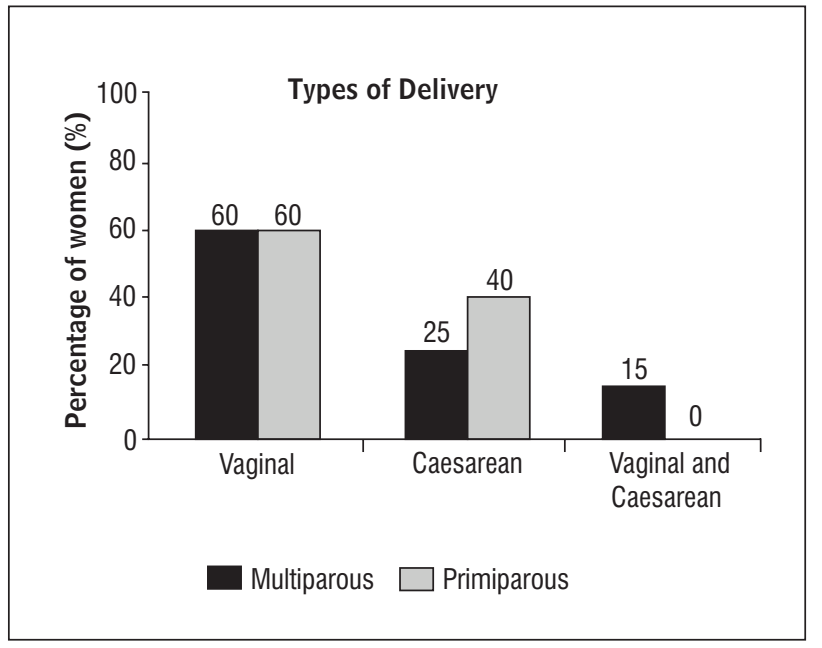

Figure $\mathbf{l}$ - Graphic representation of the type of delivery carried out by the women assessed - Campo Grande, MS, 2011

There was no significant correlation between the presence of ITU and UI in the primiparous group $(\mathrm{r}=0.16 ; \mathrm{p}=0.3)$, as well as in the multiparous group $(\mathrm{r}=0.24 ; \mathrm{p}=0.12)$.

\section{Discussion}

In the present study, the age of primiparous women ranged from 18 to 33 years old, with an average age of $22.9 \pm 3.9$ years old, whereas the age of multiparous women ranged between 18 and 36 years old, with an average age of $25.2 \pm 4.9$ years old. Higa et al. (17) report that in general population, the prevalence of IU increases according to age, which can be explained by the decrease of the vesical capacity, from 500 or $600 \mathrm{ml}$ to 250 or $300 \mathrm{ml}$.

According to the data collected in this study, there was no significant correlation between weight and urinary incontinence in the group of primiparous women as well as the comparison made with the multiparous women. However, for Higa et al. (17), obesity is a factor which compounds or contributes to the development of UI and prevalence increases with weight gaining. The association between UI and obesity is supposed to be a consequence of the high intra-abdominal pressure, caused mainly by weight gaining in the waist-hip region and, consequently, the increase of intravesical pressure changing the mechanism of the urinary tract. 
Table 1 - Mean and standard deviation values of clinical and anthropometric parameters

\begin{tabular}{|c|c|c|c|c|c|}
\hline \multirow[b]{2}{*}{ Variables } & \multicolumn{2}{|c|}{ Multiparous } & \multicolumn{2}{|c|}{ Primiparous } & \multirow[b]{2}{*}{ Value of $p^{(a)}$} \\
\hline & $n$ & $\%$ & $n$ & $\%$ & \\
\hline UI & 24 & 60.0 & 17 & 42.0 & 0.17 \\
\hline SUI & 15 & 37.5 & 14 & 35.0 & 0.84 \\
\hline Urge Inc & 9 & 22.5 & 3 & 7.5 & 0.31 \\
\hline ITU & 21 & 52.5 & 22 & 55.0 & 0.84 \\
\hline Complications & 4 & 10.0 & 3 & 7.5 & 0.84 \\
\hline HAS & 0 & 0.0 & 0 & 0.0 & \\
\hline DM & 0 & 0.0 & 0 & 0.0 & \\
\hline Period & & & & & 0.13 \\
\hline $3^{\text {rd }}$ month & 24 & 60.0 & 14 & 35.0 & \\
\hline $2^{\text {nd }}$ month & - & - & 1 & 2.5 & \\
\hline $1^{\text {st }}$ month & - & - & 1 & 2.5 & \\
\hline $1^{\text {st }}$ to $3^{\text {rd }}$ month & - & - & 1 & 2.5 & \\
\hline Discomfort & 11 & 27.5 & 10 & 25.0 & 0.84 \\
\hline
\end{tabular}

Note: (a)Mann-Whitney Test.

Santos et al. (18) report that women who participated on his research and who were obese presented a risk of stress urinary incontinence almost five times higher than those who were not obese.

Studies claim that pregnancy itself is related to the risk of causing UI, which is increased when associated to vaginal delivery and multiparity (19).

In the present research, the number of gestations, as well as the number of deliveries, was not related to the increase of UI prevalence. Dellú et al. (19) observed in their study with 194 women that the number of gestations in women with urinary symptoms and who got pregnant three or more times was shown to be statistically different from the ones who got pregnant in the same frequency, but did not shown symptoms; thus suggesting that three or more gestations could be a factor associated to urinary symptoms in the women analyzed in the study.

Guarisi et al. (20), after studying 456 women, verified that parity is one of the factors most likely to be associated to the development of urinary incontinence, what seems to be common along pregnancy, and occurs in approximately $1 / 3$ to half of all women; it is believed to be caused by a combination of mechanic and hormonal factors. However, most women stop complaining about urinary loss soon after delivery. Santos et al. (18), after analyzing 336 women, reported that multiparous women present a risk of IUE occurrence approximately ten times higher in relation to primiparous.

According to the results obtained by Scarpa et al. (21), multiparous women with four or more deliveries presented 1.29 and 1.41 times more chances to develop nocturia and pollakiuria, respectively, and 5.20 times more chances to develop nocturnal enuresis when compared to nulliparous women.

Dellú et al. (19) concluded in their study with 194 women that women who delivered twice or more had 1.57 times more risk to develop UI, regardless of the mode of delivery.

In a study carried out by Lopes (22), with 288 women, there were no statistical differences when 
comparing some kind of surgery before the last gestation to the presence of UI in postpartum, but the percentage of women with UI who had been through some kind of surgery before is higher when compared to those who did not present UI during postpartum. Higa et al. (17), when investigating the risk factors for urinary incontinence in women, noticed that there is a significant association between UI and gynecological surgeries.

In the present study, women with a previous history of gynecological surgeries were not included, as this is a risk factor for the occurrence of UI.

Martins (3), when investigating 200 puerperal women, noticed that the prevalence of UI during gestation was of $47.5 \%$. All of them referred to at least one episode of involuntary urine leakage at some point of gestation. Lopes (22) verified that from the 71 women who referred to involuntary urine leakage, 36 mentioned that the fact occurred by the end of gestation and during postpartum.

Peeker and Peeker (23) also identified that, after vaginal delivery, the prevalence of UI raises from 30 to $50 \%$. On elective caesarean deliveries, the susceptibility of developing UI is significantly reduced. However, this information is only valid for women with one or two caesarean sections, as the increase in parity has been considered a risk factor for UI, mainly after four children. In the present study there was no significant correlation between vaginal or caesarean deliveries and urinary incontinence, either in the primiparous group or the multiparous group.

Borges et al. (1), in their study with 332 women, verified that the main type of urinary incontinence mentioned was SUI, which represented half of the women who complained. Souza (13) claims that SUI during pregnancy is high, but most cases are temporary and disappear after delivery. Just a small part of the incontinent patients remain with the symptoms in puerperium.

Pereira (14) showed in his study that the urinary symptoms related to stress urinary incontinence persisted after vaginal delivery when compared to both types of caesarean deliveries.

According to Borges et al. (1), regarding mode of delivery, there has been a higher risk of SUI among women who had only vaginal deliveries. Scarpa (6) reports that women who had four vaginal deliveries had 1.8 times more chances of developing SUI when compared to the ones who had one vaginal delivery.
In this study, stress urinary incontinence occurred both in multiparous and primiparous women and this symptom was more frequent on the third trimester of gestation.

Dellú et al. (19), in their study with 194 women, verified that only $4.2 \%$ presented urge incontinence. In the present research, the prevalence of urge incontinence was shown to be relatively low when compared to SUI.

Coelho (24), when investigating the prevalence of urinary infection in pregnant women, identified that among 192 of them, 70 presented clinical alterations of ITU and 122 did not present alterations.

The frequency and severity of urinary infections during pregnancy have been acknowledged for more than a century. Besides being a relatively usual problem during pregnancy, a lot of questions about this subject still remain controversial and end up as a reason for clinical investigation (25) in the present study, there was no significant correlation between urinary tract infection and urinary incontinence in relation to primiparous and multiparous.

SUI compromises women's daily activities. Scarpa (6) observed that $35.6 \%$ of the women with UI referred to an uncomfortable sensation and this number increased to $91.9 \%$ for women with urge incontinence and SUI associated. Most women included in this research who had urinary incontinence during pregnancy did not report discomfort with this symptom.

\section{Conclusion}

Women who present urinary incontinence during pregnancy carry several risk factors associated for the occurrence of this pathology, such as: weigh gaining, parity, mode of delivery, urinary tract infection. The most incident period of this symptom was during the third gestational trimester.

In the present study, it was possible to conclude that parity and mode of delivery have not been significantly related to the occurrence of urinary incontinence during pregnancy.

Thus, further studies are necessary to verify this relation singly. However, it is known that a strengthening program for the pelvic muscles is important to avoid or even reduce these symptoms at the end of pregnancy and even after delivery. 


\section{References}

1. Borges JBR, Guarisi T, Camargo ACM, Gollop TR, Machado $\mathrm{RB}$, Borges PCG. Incontinência urinária após parto vaginal ou cesáreo. Jundiaí: Faculdade de Medicina de Jundiaí; 2010.

2. Lima JLDA. Incontinência urinária o ciclo gravídicopuerperal e impacto na qualidade de vida [dissertação]. Campinas: Universidade Estadual de Campinas; 2009.

3. Martins L. Prevalência da incontinência urinária em gestantes e puerperas das maternidades públicas de Goiânia - GO, em 2009. Brasília: Universidade de Brasília; 2010.

4. Fant JA, Newman DK, Colling J, DeLancey JO, Keeys C, Loughery R, et al. Urinary incontinence in Adults Guideline Panel. In: The Agency for Health Care Policy and Research. Urinary incontinence in adults: acute and chronic management. Rockville: AHCPR; 1996.

5. Coyne KS, Zhou Z, Thompson C, Versi E. The impact on health-related quality life of stress, urge and mixed urinary incontinence. BJU Int. 2003;92(7):731-5.

6. Scarpa KP. Prevalência de sintomas do trato urinário inferior no terceiro trimestre de gestação [dissertação]. Campinas: Universidade Estadual de Campinas; 2004.

7. Silva APS, Silva JS. A importância dos músculos do assoalho pélvico feminino, sob uma visão anatômica. Fisioter Bras. 2003;4(3):205-11.

8. Assis LC. Efetividade de exercícios do assoalho pélvico durante a gestação como medida preventiva da incontinência urinária e da disfunção muscular do assoalho pélvico [dissertação]. Botucatu: Universidade Estadual Paulista; 2010.

9. Belão CRD. Avaliação da força muscular perineal nos períodos pré e pós-operatório em mulheres submetidas à perineoplastia [monografia]. Cascavel: Universidade do Oeste do Paraná; 2004.

10. Pascoal AG. Trabalho Abdominal e Incontinência Urinária de Esforço. In: Anais do Simpósio: as mulheres e o desporto: participar, desenvolver, mudar e inovar; nov 2002; Lisboa, Portugal.
11. Praun OHJ, Busato WFS, Praun LH. Epidemiologia da incontinência urinária. In: Rubinstein, I. Incontinência urinária na mulher. São Paulo: Atheneu; 2001. p. 59-65.

12. Oliveira JM. Avaliação do efeito do tipo de parto sobre a força muscular do assoalho pélvico de primíparas [dissertação]. Ribeirão Preto: Universidade de São Paulo; 2007.

13. Souza APP. Prevalência dos sintomas urinários na gestação de baixo risco em usuárias do Sistema Único de Saúde (SUS) [dissertação]. Rio de Janeiro: Universidade Estácio de Sá; 2008.

14. Pereira SB. Impacto do parto na atividade eletromiográfica do assoalho pélvico e nos sintomas do trato urinário inferior: estudo prospectivo comparativo [tese]. Campinas: Universidade Estadual de Campinas; 2008.

15. Potrick BA. Eletroestimulação transvaginal do assoalho pélvico no tratamento da incontinência urinaria de esforço: avaliação clínica, urodinâmica e ultrasonográfica [dissertação]. Campinas: Universidade Estadual de Campinas; 2002.

16. Rett MT, Simões JA, Herrmann V, Gurgel MSC, Morais SS. Qualidade de vida em mulheres após tratamento da incontinência urinária de esforço com fisioterapia. Rev Bras Ginecol Obstet. 2007;29(3):134-40. doi: 10.1590/S0100-72032007000300004.

17. Higa R, Lopes MHBM, Reis MJ. Fatores de risco para incontinência urinária na mulher. Rev Esc Enferm USP. 2008;42(1):187-92.

18. Santos PC, Mendonça D, Alves O, Barbosa AM. Prevalência e impacte da incontinência urinária de stresse antes e durante a gravidez. Act Med Port. 2006; 19(5):349-56.

19. Dellú MC, Zacaro PMD, Schmitt ACB. Prevalência de sintomas urinários e fatores obstétricos associados em mulheres adultas. Rev Bras Fisioter. 2008; 12(6):482-7.

20. Guarisi T, Pinto Neto AM, Osis MJ, Pedro AO, Paiva LH, Faúndes A. Incontinência urinária entre mulheres climatéricas brasileiras: inquérito domiciliar. Rev Saúde Pública. 2001;35(5):428-35. 
21. Scarpa KP, Herrmann V, Palma PCR, Ricetto CLZ, Morais S. Prevalência de sintomas urinários no terceiro trimestre da gestação. Rev Assoc Med Bras. 2006; 52(3):153-6.

22. Lopes DBM. Prevalência e fatores associados de incontinência urinária autorreferida no pós-parto [dissertação]. São Paulo: Universidade de São Paulo; 2010.

23. Peeker I, Peeker R. Early diagnosis and treatment of genuine stress urinary incontinence in woman after pregnancy: midwives as detectives. J Midwifery Womens Health. 2003;48(1):60-6.

24. Coelho F, Sakae TM, Rojas PFB. Prevalência de infecção do trato urinário e bacteriúria em gestantes da clínica ginecológica do Ambulatório Materno Infantil de Tubarão-SC no ano de 2005. Arq Catarin Med. 2008;37(3):44-55.
25. Duarte G, Marcolin AC, Gonçalves CV, Quintana SM, Berezowsky AT, Nogueira AA, et al. Infecção urinária na gravidez: análise dos métodos para diagnóstico e do tratamento. Rev Bras Ginecol Obstet. 2002; 24(7):471-7.

Received: 03/12/2014

Recebido: $12 / 03 / 2014$

Approved: 09/23/2014

Aprovado: 23/09/2014 